\section{$\underset{\substack{\text { hommes } \\ \text { \& migrations }}}{ }$}

\section{Hommes \& migrations}

Revue française de référence sur les dynamiques

migratoires

\section{$1322 \mid 2018$}

Exposer les migrations

\title{
Patricia Reznikov, Le Songe du photographe, Albin Michel, 2017, 328 p., 21,50€.
}

\section{Mustapha Harzoune}

\section{(2) OpenEdition}

\section{Journals}

Édition électronique

URL : https://journals.openedition.org/hommesmigrations/6939

DOI : 10.4000/hommesmigrations.6939

ISSN : 2262-3353

\section{Éditeur}

Musée national de l'histoire de l'immigration

\section{Édition imprimée}

Date de publication : 1 juillet 2018

Pagination : 215-216

ISBN : 978-2-919040-42-1

ISSN : $1142-852 X$

Référence électronique

Mustapha Harzoune, «Patricia Reznikov, Le Songe du photographe, Albin Michel, 2017, 328 p.,

21,50 €. », Hommes \& migrations [En ligne], 1322 | 2018, mis en ligne le 01 juillet 2018, consulté le 21

janvier 2022. URL : http://journals.openedition.org/hommesmigrations/6939; DOI : https://doi.org/

10.4000/hommesmigrations.6939 


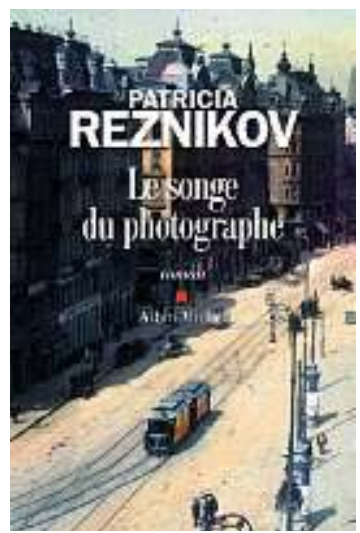

Imaginez un Russe, une Autrichienne, un Hongrois, un Cubain... sous le même toit. En exil à Paris. Un éternel exil. Imaginez qu'un ado débarque dans cette maison que le commun des mortels, modernisé et bien propret, qualifierait de fous. À l'intérieur, on y parle russe, hongrois ou allemand; on s'engueule et s'invective ; on pleure de vieux souvenirs, convoque des fantômes et chérit de vieux objets et de gourmandes recettes ; on ressasse de vieux drames, on refait I'histoire, celle de l'Europe de l'Est : un après-midi de novembre 1977, du côté de "l'impasse des Artistes et sa maison de bohémiens ". "Ce furent ces artistes-là qui me sauvèrent ": Sándor, un juif hongrois, Sergueï Vladimirovitch, un russe blanc, Angel, prof de salsa et peintre cubain, Magda, juive autrichienne, et la "mystérieuse » Dorika.

Joseph débarque sur cette planète cosmopolite, il découvre l'amitié, l'humour, le sens de la fête et du partage, les vertus, même trompeuses, de la résilience, un peu d'excès et de folie aussi, celle qui rime avec poésie et, titre oblige, photographies, celles prises par une tripotée de "photographes volants" venus de l'Est qui « ont écrit avec la lumière l'histoire de ce monde avant qu'il ne s'éteigne. Avant la nuit noire ". Joseph va se nourrir de ce qu'il n'a pas chez lui : accueil, écoute, estime, considération, amour.De quoi se reconstruire. L'alchimie joue à plein : " J'étais aussi une oreille de premier choix pour leurs névroses explosives, leurs tourments multicolores, leurs nostalgies chantantes, leurs gueules de bois. J'étais le parfait élève en traumatismes des réfugiés, en cabossés de l'Histoire, en poètes déracinés. Etjene demandais qu'à apprendre. » Et lui, exilé à lui-même, va apprendre, recevoir comme un legs le viatique de l'exil : "Aujourd'hui, sans eux, sans leur extraordinaire talent pour inventer la vie, tous les jours, qu'il pleuve ou qu'il vente, 


\section{LIVRES}

que les nouvelles soient bonnes ou non, malgré les blessures, je ne serais rien. Ils ont fait de moi un homme. Un Mensch, comme dirait Magda. Ils avaient ce pouvoir de semer de la poésie partout où ils mettaient les pieds et de convoquer la vie même. Grâce à eux, la beauté aura poussé dans mon cour." "

Les pages consacrées à cette maison de "bohémiens » sont les plus enthousiasmantes. II y a là comme un écho au Club des incorrigibles optimistes de Jean-Michel Guenassia ou à La Maison russe de Tania Sollogoub. Avec moins de souffle. Car ici, la lecture est comme ralentie, contrariée par la construction, ces longs développements historiques qui ramènent à l'histoire, à la nuit européenne. Dans ce trop-plein de documentation, les personnages finissent par s'effacer, quand ce sont justement "Magda, Sándor, Sergueï, Angel et les autres, leurs parents, leurs voisins " qui importent, et la question de savoir "Quelles lumières ont-ils allumées pour nous? " Pour Joseph, qui incarne cette nouvelle génération, "celle des enfants de cons qui vont devoir se débrouiller pour redresser le monde".

M. H. 